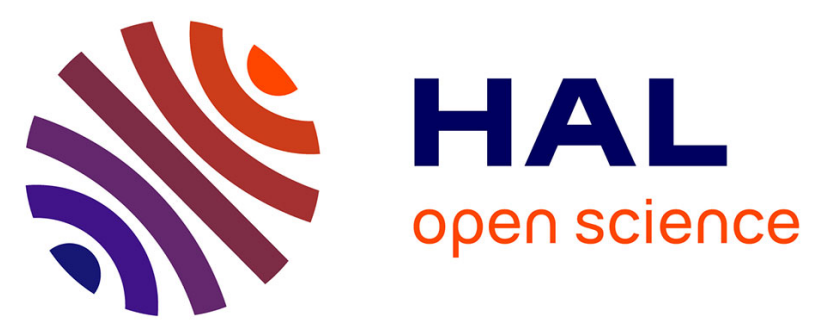

\title{
Detection and characterization of methicillin-resistant and susceptible coagulase-negative staphylococci in milk from cows with clinical mastitis in Tunisia.
} Amira Klibi, Abderrazek Maaroufi, Carmen Torres, Ahlem Jouini

\section{- To cite this version:}

Amira Klibi, Abderrazek Maaroufi, Carmen Torres, Ahlem Jouini. Detection and characterization of methicillin-resistant and susceptible coagulase-negative staphylococci in milk from cows with clinical mastitis in Tunisia.. International Journal of Antimicrobial Agents, 2018, 52 (6), pp.930-935. 10.1016/j.ijantimicag.2018.07.026 . pasteur-02003124

\section{HAL Id: pasteur-02003124 \\ https://hal-riip.archives-ouvertes.fr/pasteur-02003124}

Submitted on 1 Feb 2019

HAL is a multi-disciplinary open access archive for the deposit and dissemination of scientific research documents, whether they are published or not. The documents may come from teaching and research institutions in France or abroad, or from public or private research centers.
L'archive ouverte pluridisciplinaire HAL, est destinée au dépôt et à la diffusion de documents scientifiques de niveau recherche, publiés ou non, émanant des établissements d'enseignement et de recherche français ou étrangers, des laboratoires publics ou privés. 


\section{Accepted Manuscript}

Detection and characterization of methicillin resistant and susceptible coagulase-negative Staphylococci in milk from cows with clinical mastitis in Tunisia.

Amira Klibi , Abderrazek Maaroufi , Carmen Torres , Ahlem Jouini

PII:

DOI:

Reference:

To appear in:

Received date:

Revised date:

Accepted date:
S0924-8579(18)30225-5

https://doi.org/10.1016/j.jiantimicag.2018.07.026

ANTAGE 5507

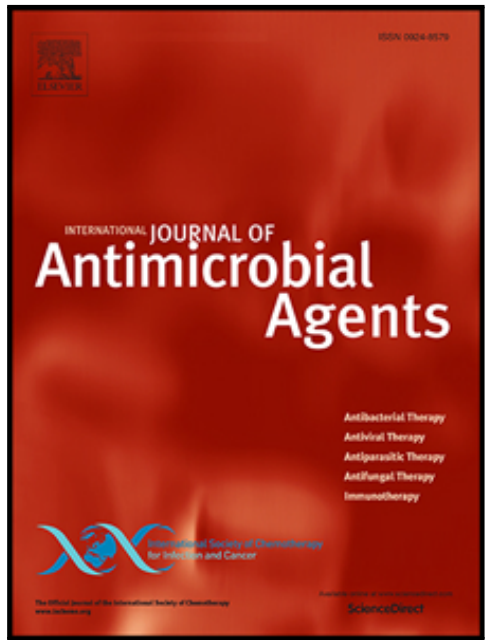

International Journal of Antimicrobial Agents

Please cite this article as: Amira Klibi, Abderrazek Maaroufi, Carmen Torres, Ahlem Jouini , Detection and characterization of methicillin resistant and susceptible coagulase-negative Staphylococci in milk from cows with clinical mastitis in Tunisia., International Journal of Antimicrobial Agents (2018), doi: https://doi.org/10.1016/j.ijantimicag.2018.07.026

This is a PDF file of an unedited manuscript that has been accepted for publication. As a service to our customers we are providing this early version of the manuscript. The manuscript will undergo copyediting, typesetting, and review of the resulting proof before it is published in its final form. Please note that during the production process errors may be discovered which could affect the content, and all legal disclaimers that apply to the journal pertain. 


\section{Highlights}

- Detection of different species of SCN implicated in milk mastitis with predominance of S. xylosus.

- MR-CNS isolates harboring mecA gene with different resistance genes for erythromycin and tetracycline.

- SCCmec type-Iva and recombinase genes $c c r \mathrm{~A} 2 / \mathrm{B} 2$-classe B mec gene complex were detected in MRSE.

- Low resistance rate in MS-SCN with some resistance gene for erythromycin and tetracycline.

- $t s t$ genes responsible for toxic shock syndrome is detected only in one methicilin resistant strain. 
Detection and characterization of methicillin resistant and susceptible coagulasenegative Staphylococci in milk from cows with clinical mastitis in Tunisia.

Amira Klibi ${ }^{1}$, Abderrazek Maaroufi ${ }^{1}$, Carmen Torres ${ }^{2}$ and Ahlem Jouini ${ }^{1 *}$

${ }^{1}$ Laboratory of Epidemiology and Veterinary Microbiology, Goup of Bacteriology and Biotechnology developement. Pasteur Institute of Tunis, BP 74, 13 place Pasteur, Belvédère, 1002 Tunis, Tunisia. Université de Tunis El Manar, 2092 Tunis, Tunisie

${ }^{2}$ Area of Biochemistry and Molecular Biology, University of La Rioja, Logroño, Spain.

*Corresponding author

Ahlem Jouini, $\mathrm{PhD}$

Laboratory of Epidemiology and Veterinary Microbiology, Group of Bacteriology and Biotechnology developement. Pasteur Institute of Tunis, BP 74, 13 place Pasteur, Belvédère, 1002 Tunis, Tunisia. Université de Tunis El Manar, 2092 Tunis, Tunisie. Phone: 21671783 022, e-maik: ahlem.jouini@pasteur.rns.tn 


\section{Abstract}

The prevalence of methicillin-resistant (MR) and methicillin-susceptible (MS) coagulasenegative staphylococci (CNS) and the implicated mechanisms of resistance and virulence were investigated in milk of mastitis cows. In addition the presence of SCCmec type is analyzed in MR Staphylococcus epidermidis (MRSE). Three hundred milk samples from bovine with clinical mastitis were obtained from 30 dairy farms in different regions of Tunisia. Sixty-eight of the 300 tested samples contained CNS strains. Various CNS species were identified, being S. xylosus the most frequently found (40\%), followed by S. warneri (12\%). The mecA gene was present in 14 of 20 MR-CNS isolates. All of them lacking the $m e c \mathrm{C}$ gene. The SCCmecIVa was identified in four MRSE isolates. Most of CNS isolates showed penicillin resistance $(70.6 \%)$ and $58.3 \%$ of them carried the blaZ gene. MR-CNS isolates $(n=20)$ showed resistance to erythromycin, tetracycline and trimethoprimsulfametoxazole harboring different resistancé genes such us $\operatorname{erm}(\mathrm{B}), \operatorname{erm}(\mathrm{T}), \operatorname{erm}(\mathrm{C}), \operatorname{mph}(\mathrm{C})$ or $m s r(\mathrm{~A}), \operatorname{tet}(\mathrm{K})$ and $d f r(\mathrm{~A})$ genes. However, a lower percentage of resistance was observed among 48 MS-CNS isolates: erythromycin (8.3\%), tetracycline (6.2\%), streptomycin $(6.2 \%)$, clindamycin (6.2\%), and trimethoprim-sulfametoxazole (2\%). The $\operatorname{Inu}(\mathrm{B})$ gene was detected in one $S$. xylosus strain which showed clindamycin-resistance. The virulence gene tsst- 1 was observed in one MR-CNS strain. CNS containing a diversity of antimicrobial resistance genes are frequently detected in milk of mastitis cows. This fact emphasizes the importance of identification of CNS when an intramammary infection is present because of the potential risk of lateral transfer of resistant genes among staphylococcal species and other pathogenic bacteria. 
Keywords: MR-CNS, MS-CNS, resistance and virulence genes, mecA, SCCmec MRSE, bovine mastitis.

\section{Introduction}

Coagulase-negative staphylococci (CNS) play a role as opportunistic nosocomial pathogens in human medicine. They are often involved in foreign body infections and eatheter-related infections, but also in urinary tract infections and endocarditis, among others [1]. Nowadays, CNS are of great interest in veterinary medicine because they are currently considered emerging pathogens of bovine mastitis. In dairy farms, mastitis remains an important disease with high economic effect. Among the etiologic agents of mastitis bovine, staphylococci is the main type of microorganisms, with some coagulase-positive species ( $S$. aureus) associated with more severe illness than CNS [2]. CNS form a heterogeneous group of over 50 species and subspecies that are traditionally considered to be minor pathogens. However, CNS are increasingly being recognized as an important cause of clinical and subclinical bovine mastitis worldwide [3,4]. These microorganisms can cause persistent infections leading to an increased number of somatic cells, changes in milk composition and reduction of production [3]. The treatment of mastitis by extensive use of antibiotics in dairy cows induce antimicrobial resistance that staphylococci might acquire and is considered one of the main reasons for low cure rate of mastitis [5]. It is known that CNS species tend to be more resistant to antimicrobials than S. aureus, and they easily develop multi-resistance [3]. The production of $\beta$-lactamase is an important acquired resistance mechanism among bovine CNS which confers resistance to aminopenicillins. Resistance also to aminoglycosides, tetracyclines, and macrolides has been described [6,7]. Interestingly, MR in staphylococci is mainly conferred by the spreading of mecA gene that complicate the treatment of the infection related to MR-CNS, representing a public health risk [8]. The mecA gene, which encodes 
PBP2a, is carried by a mobile genetic element, the staphylococcal cassette chromosome mec (SCCmec), which contains the mec complex genes, its regulators and the $c c r$ gene complex, which encodes site-specific recombinases that are responsible for the mobility of the element. In fact, 11 types of SCCmec (I-XI) have been defined in Staphylococcus isolates [10]. Recently, a new divergent mecA homolog (mecC) was described in a novel SCCmec designated as type XI [10]. Furthermore, mecA-positive CNS may act as potential donors for the creation of new MR Staphylococcus aureus (MRSA) clones [9]. The pathogenicity of CNS could be associated to the production of several virulence factors such as the enterotoxins, the Panton-Valentine leukocidin (PVL) or the toxic shock syndrome toxin 1 (TSST-1) [3]. Biofilm production, a recognized virulence factor in staphylococci, has been proposed as a significant element in the persistence of bovine intra-mammary infections [11]. Methicillin-resistant staphylococci are increasingly being isolated in bovine mastitis and the use of antimicrobials can be an important tool in the mastitis control programs. The close contact of humans and animals in dairy farms can present a great risk for the transmission of bacteria between animal and human hosts [8]. Therefore, surveillance of antimicrobial resistance and surveillance of CNS is important to minimize the risk for development and spread of antimicrobial resistance and virulence genes. The goal of this study was to determine the incidence of antibiotic resistance and virulence determinants among different species of CNS isolated from cows with clinical mastitis in Tunisia.

\section{Materials and methods}

\subsection{Origin of Samples}

Three-hundred milk samples were collected from 300 cows that showed clinical mastitis symptoms (one sample/cow). Samples were obtained of 30 farms with intensive breeding across different regions in North and South of Tunisia, during October 2013 to September 2014. The farms included in this study were involved in the production of milk for self- 
consumption, cheese production, and milk bottling. Each cow was clinically diagnosed by the appearance of general clinical signs related to udder and teats and the presence of any of the gross abnormalities such as fibrosis, inflammatory swellings, pain, visible injury or lesion, atrophy of the tissue and teat blindness. The milk sample was observed for changes regarding color, odor and consistency. The presence of clots, flakes, blood and other consistent changes were indicators of clinical mastitis along with udder and teat morphological changes. A milk sample of one infected quarter was obtained from the 300 tested mastitis cows by veterinarians. Before taking the milk samples, teats were washed thoroughly and dried. They were then sprayed with $70 \%$ ethanol, the first few squirts of milk were discarded, and $30 \mathrm{ml}$ milk samples were collected in sterile tubes. The milk samples were transferred to the laboratory in cooler and immediately processed. It is important to note that the studied cows did not receive any antibiotic therapy.

\subsection{Isolation and identification of staphylococcus species}

One $\mathrm{ml}$ of each milk sample was suspended in sterile saline solution for serial dilutions and then they were seeded on Baird Parker (BP, Biolife) for Staphylococus recovery. All the plates were incubated at $37^{\circ} \mathrm{C}$ for $24-48 \mathrm{~h}$. Isolates with typical staphylococci morphology were selected (one per sample) and identified by classical biochemical methods [Gram staining, oxydase, catalase, DNase, and ability to coagulate rabbit plasma (Bio-Rad)] [12]. The CNS strains were submitted to molecular identification by amplification and sequencing of $\operatorname{sodA}$ gene [13].

\subsection{Antimicrobial susceptibility testing}

Antimicrobial susceptibility testing for 15 antimicrobial agents was performed using the diskdiffusion method in accordance with the Clinical and Laboratory Standards Institute (CLSI) recommendations [14]. Antimicrobial agents tested ( $\mu \mathrm{g} / \mathrm{disk})$ were as follows: penicillin (10), 
oxacillin (1), cefoxitin (30), kanamycin (30), gentamicin (10), tobramycin (10), tetracycline (30), chloramphenicol (30), trimethoprim-sulfamethoxazole (1.25/23.75), erythromycin (15), clindamycin (2), ciprofloxacin (5), vancomycin (30), and teicoplanin (30). Methodology and guidelines for streptomycin $(10 \mu \mathrm{g} / \mathrm{disk})$ were as recommended by the European committee on antimicrobial susceptibility testing [15].

\subsection{Detection of antimicrobial resistance genes}

Detection of antimicrobial resistance genes was performed by PCR, according to the resistance phenotype $[\operatorname{bla}(\mathrm{Z}), \operatorname{ant}(4)-\mathrm{Ia}, \operatorname{dfr}(\mathrm{A}), \operatorname{catp} \mathrm{C} 221, \operatorname{tet}(\mathrm{K}), \operatorname{tet}(\mathrm{M}), \operatorname{tet}(\mathrm{L}), \operatorname{erm}(\mathrm{A})$, $\operatorname{erm}(\mathrm{B}), \operatorname{erm}(\mathrm{T}), \operatorname{erm}(\mathrm{C}), \operatorname{mph}(\mathrm{C}), \ln u(\mathrm{~A}), \ln u(\mathrm{~B}), \operatorname{In} u(\mathrm{C}), \operatorname{vga}(\mathrm{A}), \operatorname{vga}(\mathrm{B}), \operatorname{vga}(\mathrm{C})$, $m s r(\mathrm{~A}) / m s r(\mathrm{~B})$ genes] [16,17].

\subsection{Detection of mecA and mecC genes}

Methicillin-resistance was detected by oxacillin and/or cefoxitin susceptibilities by the diskdiffusion agar according to CLSI, 2015. Confirmation of methicillin resistance was performed by conventional PCR targeting the mecA gene [18], and S. aureus ATCC 43300 was used as control strain. All mecA negative CNS isolates with oxacillin or cefoxitin resistance were tested for the presence of mecC gene by PCR [19]. A positive control MRSA strain (C7697) of $m e c \mathrm{C}$ gene from the collection of the University of La Rioja (Logroño, Spain) were used in each PCR assay [19].

\subsection{SCCmectyping in MRSE isolates}

The presence of SCCmec types I to V was investigated in MRSE isolates by PCR of the $c c r$ recombinases (1-5) and the mec gene complex type (A to $\mathrm{C}$ ), as recommended by the International Working Group on the Classification of Staphylococcal Cassette Chromosome Elements (IWG-SCC) [20]. An additional PCR was performed to differentiate the subtypes of SCCmec IV (a-d) [18]. 


\section{Detection of staphylococcal toxin genes and biofilm production}

All isolates were tested by PCR for the presence of the toxic shock syndrome toxin 1(tsst-1), leukocidin of Panton Valentine (PVL, lukF-lukS-PV) and exfoliative ETA/ETB toxins (etA and $e t \mathrm{~B}$ genes). Furthermore, the presence of genes coding for the formation of biofilm (icaA, icaB) was determined by PCR [21].

\section{Results}

\subsection{Distribution of CNS species}

Isolates were collected from milk samples of cows with symptoms of clinical mastitis across different regions in North and South of Tunisia. Of the 300 samples tested, 83 milk samples showed the growth of staphylococci and one isolate per sample was further characterized. Sixty-eight of these strains (82\%) were presumptively identified as CNS according to their morphology in BP media. The remaining fifteen staphylococci were identified as $S$. aureus isolates and were previously characterized [22]. The molecular identification by amplification and sequencing of sodA gene of the $68 \mathrm{CNS}$ isolates in this study revealed the presence of 11 different species (number of isolates): S. xylosus (27), S. warneri (8), S. chromogenes (6), S. sciuri (5), S. epidermidis (5), S. pasteuri (5), S. haemolyticus (4), S. succinus (3), S. equorum (2), S. saprophyticus (2) and S. cohnii (1).

\subsection{Identification of methicillin resistance among CNS isolates}

Screening of MR was performed by oxacillin and/or cefoxitin disc diffusion. Twenty of 68 CNS isolates (29.41\%) showed oxacillin and/or cefoxitin resistance and 14 of them carried the mecA gene (1 S. scuiri, 1 S. warneri, 4 S. epidermidis, 2 S. haemolitycus, 4 S. pasteuri, 1 S. chromogenes, and $1 \mathrm{~S}$. cohnii); the remaining $6 \mathrm{MR}-\mathrm{CNS}$ isolates were mecA and mecC genes negative (all of them were cefoxitin-resistant) (Table1). 


\subsection{Detection of antimicrobial resistance phenotypes and genotypes in MR-CNS and MS-CNS}

Eleven of 20 MR-CNS strains showed erythromycin-resistance and harbored the erm(B), $\operatorname{erm}(\mathrm{T}), \operatorname{erm}(\mathrm{C}), \operatorname{mph}(\mathrm{C})$ or $m \operatorname{sr}(\mathrm{A})$ genes; four strains were tetracycline-resistant (with $\operatorname{tet}(\mathrm{K})$ gene), and eight strains trimethoprim-sulfamethoxazole-resistant (with $d f r(\mathrm{~A})$ gene in three of these isolates). The blaZ gene was detected in 15/17 MR-CNS. Other resistances detected were as follows: clindamycin $(n=14)$, gentamicin $(n=4)$, ciprofloxacin $(n=5)$, streptomycin $(n=6)$, tobramycin $(n=2)$, and chloramphenicol $(n=1)$. No resistance genes for tetracycline and erythromycin were detected in some of the isolates (Table 1). Ten MR strains showed a resistance to 3 or 4 different antibiotics families.

Concerning the $48 \mathrm{MS}-\mathrm{CNS}$ isolates, most of them showed penicillin resistance (31 isolates, 13 of them with blaZ gene). Tetracycline resistance was detected in only three strains, encoded by tetK gene. Macrolide resistance was noted in four strains with the presence of $\operatorname{erm}(\mathrm{C})(\mathrm{n}=2), \operatorname{erm}(\mathrm{T})(\mathrm{n}=1)$ and $\operatorname{msr}(\mathrm{A})(\mathrm{n}=2)$ genes. It is noted that these three genes are present in one strain. The $\operatorname{Inu}(\mathrm{B})$ gene was detected in one clindamycin-resistant S. xylosus strain.

\subsection{Detection of virulence genes in CNS isolates}

Virulence trait characterization revealed that only one MR-CNS isolate (mecA-positive $S$. chromogenes) harbored the virulence gene tsst-1, and none of them were positive for enterotoxins, $p v l$, et $\mathrm{A}$, et $\mathrm{B}$ or the $i c a \mathrm{~A}, i c a \mathrm{~B}$ genes.

\subsection{Molecular typing of $S$. epidermidis isolates}

The SCCmec type-IVa was identified in all four MRSE isolates which also exhibited the recombinase genes $c c r \mathrm{~A} 2 / \mathrm{B} 2$-classe $\mathrm{B}$ mec gene complex.

\section{Discussion}


To the best of our knowledge, there is no published information regarding MR-CNS from bovine mastitis in Tunisia and in Africa. Only very limited data on the prevalence and molecular characterization of MR-CNS isolated from hospital, animals and food are available in Africa (Tunisia, Egypt and Nigeria) [23,24,25]. CNS is an important etiological agent of mastitis in cattle worldwide, including South Africa [26,20,27,3,28]. Staphylococcal species were detected in $27.7 \%$ of bovine clinical mastitis milk samples, in most of the cases of the CNS group (82\%). Our investigation revealed a high diversity of staphylococcal species among CNS (S. xylosus, S. warneri, S. chromogenes, S. scuiri, S. epidermidis, S. pasteuri, S. haemolyticus, S. succinus, S. equorum, S. saprophyticus and S. cohnii). The CNS species most often isolated in our survey were S. xylosus $(39.7 \%)$ followed by $S$. warneri $(11.8 \%)$. This observation confirms the previous studies reported by Kot el al. [29] and Bochniarz et al. [30], who showed that S. xylosus was the most frequently species isolated of milk samples of bovine mastitis. S. xylosus seems to be a versatile organism, but little is known about its epidemiology in mastitis [31]. S. warneri was also reported by Klimiene et al. [4], which is the second species isolated and described as a minor pathogen of intra-mammary infection. According to Mork et al. [32], S. warneri cannot survive in the udder for a long period of time and thus cannot cause persistent mastitis [33]. A low number of other species was detected, in fact, the distribution of staphylococcal species varies between studies, but S. chromogenes, $S$. epidermidis, S. haemolyticus and S. simulans are commonly found [6]. The resistance to methicillin was confirmed by the presence of the mecA gene in 14 isolates, constituting $20.6 \%$ of all CNS isolates. Methicillin-resistance among CNS was similar to that found in Poland (20\%) and in China (17.1\%) [30,27]. However, low percentages of MR-CNS isolates from bovine mastitis was reported in Portugal (9.3\%) and Brazil (4.6\%) [34,20]. It is important to note that the presence of mecA gene has been detected in diverse CNS species $(S$. scuiri, S. warneri , S. epidermidis, S. haemolitycus, S. pasteuri, S. chromogenes and S. 
cohnii), which is similar to what was reported previously [35]. Methicillin-resistant staphylococci have been reported in milk samples from dairy cattle and surveillance of this resistance trait is important for public health and veterinary medicine [36]. MecA-positive $S$. epidermidis isolates have been found in this study, a putative zoonotic pathogen; these strains carried the SCCmec type-IVa, what is in agreement with the report of Silva et al. [20]. In fact, the relatively smaller size of this cassette (20-24 kb) compared with other types of SCCmec may facilitate its transference among staphylococci [10]. However, the presence of MRSE strains in bovine milk samples is a matter of concern as they may act as a reservoir of genetic elements carrying antimicrobial resistance. Because of their mobile nature, the SCCmec elements can be transferred to other species of staphylococci including S. aureus [37]. A possible mechanism to explain the phenotype of resistance to oxacillin and/or cefoxitin in the absence of the mecA gene would be the overproduction of $\beta$-lactamase, the production of a new methicillinase, or the change in the penícillin-binding proteins [37]. Our results showed that resistance to penicillin was observed frequently among CNS isolates $(n=48)$ and 28 isolates $(58.33 \%)$ harbored the blaZ gene. The higher prevalence of this gene may be due to the frequent use of penicillin for dairy cow therapy in Tunisia. The blaZ gene in CNS isolates from mastitis milk was also reported in Switzerland (90.7\%), Lithuania (66\%) and China (30.3\%) [7,27,4]. MR-CNS isolates showed resistance to other antibiotics such as erythromycin, tetracycline, clindamycin, gentamicin, ciprofloxacin, streptomycin, tobramycin, chloramphenicol and trimethoprim-sulfamethoxazole, and they harbored the $\operatorname{erm}(\mathrm{B}), \operatorname{erm}(\mathrm{T})$, $\operatorname{erm}(\mathrm{C}), \operatorname{mph}(\mathrm{C}), \operatorname{msr}(\mathrm{A}), \operatorname{tet}(\mathrm{K})$ or $d f r(\mathrm{~A})$ genes. On the other hand, the MS-CNS isolates showed susceptibility to the tested antimicrobials, with some exceptions due to the presence of $\operatorname{erm}(\mathrm{B}), \operatorname{erm}(\mathrm{C}), \operatorname{erm}(\mathrm{T}), \operatorname{msr}(\mathrm{A}), \operatorname{mph}(\mathrm{C})$ and $\operatorname{tet}(\mathrm{K})$ genes. It's important to note, that tetracycline resistance was encoded only by the tet $(\mathrm{K})$ gene in both groups, being this resistance gene very frequent in staphylococci species [29]. According to our study, the 
simultaneous presence of two or more macrolide resistance genes in the CNS isolates is well known and has been reported previously in S. aureus or in CNS isolates from bovine mastitis [38].

Virulence trait characterization revealed that only one isolate MR-CNS (S. chromogenes mecA positive) harbored the virulence gene tsst-1 and none of them were positive for enterotoxins genes, the exfoliative toxin genes $(e t \mathrm{~A}$, et $\mathrm{B})$, the intracellular adhesion genes $(i c \mathrm{~A}, i c \mathrm{~B})$ and the $l u k F-l u k S-\mathrm{PV}$ gene. The presence of enterotoxin and $l u k F-l u k S-\mathrm{PV}$ genes in CNS isolated from bovine mastitis has been previously described [12]. Compared to $S$. aureus, only few studies were focused on the prevalence of virulence genes in CNS isolated from cows with mastitis $[39,40]$.

\section{Conclusion}

Antimicrobial resistance in CNS, mainly for beta-lactams and tetracycline, is high in isolates recovered from milk of mastitis cows, what may be caused by the use of these compounds in Tunisian farms. The identification of Staphylococcus species and the surveillance of antimicrobial resistance are important to minimize the risk of the spread of antimicrobial resistance but also the possible risk of transmission of these microorganisms between cows and in-contact humans. Moreover, the potential transmission of antibiotic resistance could affect not only to Tunisian cattle breeding but also in neighboring countries across the exportation of milk products or Tunisian breed cows.

\section{Acknowledgments}

We thank Dr R.B Elandolsi veterinary in the Tunisian laboratory for providing the samples. 


\section{Declarations}

Funding: This work was supported by internal collaborative project of Pasteur Institute of Tunis and the Tunisian Ministry of Higher Education, Scientific Research and Technology (LR11IPT03).

\section{Competing Interests: No}

Ethical Approval: The study underwent ethical review and was given approval by the BioMedical Ethics Animal Committee at Pasteur Institute of Tunis, ref 2016/16/I/LR11IPT03/V0 


\section{References}

[1] Febler AT, Billerbeck C, Kadlec K, Schwarz S. Identification and characterization of methicillin-resistant coagulase-negative staphylococci from bovine mastitis. J Antimicrob Chemother 2010;65:1576-1582.

[2] Bradley AJ, Leach KA, Breen JE, Green LE, Green MJ. Survey of the incidence and etiology of mastitis on dairy farms in England and Wales. Vet Rec 2007;160:253-257.

[3] Pyorala S, Taponen S. Coagulase-negative staphylococci-emerging mastitis pathogens. Vet Microbiol 2009;134:3-8.

[4] Klimiene I, Virgailis M, Pavilonis A, Siugzdiniene R, Mockeliunas R, Ruzauskas M. Phenotypical and genotypical antimicrobial resistance of coagulase-negative staphylococci isolated from cow mastitis. Pol J Vet Sci 2016;639-646.

[5] Barkema HW, Green MJ, Bradley AJ, Zadoks RN. Invited review: the role of contagious disease in udder health. J Dairy Sci 2009; 92:4717-4729.

[6] Persson Waller K, Aspán A, Nyman A, Persson Y, Grönlund Andersson U. CNS species and antimicrobial resistance in clinical and subclinical bovine mastitis. Vet Microbiol 2011;152:112-116

[7] Frey Y, Rodriguez JP, Thomann A, Schwendener S, Perreten V. Switzerland Genetic characterization of antimicrobial resistance in coagulase-negative staphylococci from bovine mastitis milk. J Dairy Sci 2013;96:2247-2257.

[8] Juhasz-Kaszanyitzky E, Janosi S, Somogyi P, Dan A, van der Graaf-van Bloois L, van Duijkeren E, Wagenaar JA: MRSA transmission between cows and humans. Emerg Infect Dis 2007;13:630-632.

[9] Hanssen AM, Ericson Sollid JU. SCCmec in staphylococci: genes on the move. FEMS 
Immunol Med Microbiol 2006;46:8-20.

[10] Becker K, Ballhausen B, Kock R, Kriegeskorte A. Methicillin resistance in Staphylococcus isolates: The "mec alphabet" with specific consideration of mecC, a mec homolog associated with zoonotic S. aureus lineages. Int J Med Microbiol 2014;304:794804.

[11] Tremblay YDN, Lamarche D, Chever P, Haine D, Messier S, Jacques M. Characterization of the ability of coagulase negative staphylococci isolated from the milk of Canadian farms to form biofilms. J Dairy Sci 2013;96:234-246.

[12] de Freitas Guimaraes F, Nobrega DB, Richini-Pereira VB, Marson PM, de Figueiredo JC, Langoni H. Enterotoxin genes in coagulase-negative and coagulase-positive staphylococci isolated from bovine milk. J Dairy Sci 2013;96:2866-2872.

[13] Poyart C, Quesne G, Boumaila C, Trieu-Cuot P. Rapid and accurate species-level identification of coagulasenegative staphylococci by using the sodA gene as a target. J Clin Microbiol 2001;39:4296-4301.

[14] Clinical and Laboratory Standards Institute (CLSI). Performance Standards for Antimicrobial Susceptibility Testing; Twenty-Fifth Informational Supplement. CLSI document M100-S25. Wayne, PA: CLSI, 2015.

[15] [EUCAST] European Committee on Antimicrobial Susceptibility Testing. (2015) (http://www.eucast.org/)

[16] Gomez-Sanz E, Torres C, Lozano C, Fernandez-Perez R, Aspiroz C, Ruiz-Larrea F, Zarazaga M. Detection, molecular characterization, and clonal diversity of methicillinresistant Staphylococcus aureus CC398 and CC97 in Spanish slaughter pigs of different age groups. Food Path Dis 2010;7:1269-1277 
[17] Wendlandt S, Lozano C, Kadlec K, Go’mez-Sanz E, Zarazaga M, Torres C, Schwarz S. The enterococcal ABC transporter gene lsa(E) confers combined resistance to lincosamides, pleuromutilins and streptogramin A antibiotics in methicillin-susceptible and methicillin resistant Staphylococcus aureus. J Antimicrob Chemother 2013;268:473-475.

[18] Zhang K, Sparling J, Chow BL, Elsayed S, Hussain Z, Church DL, Gregson DB, Louie T, Conly JM. New quadriplex PCR assay for detection of methicillin and mupirocin resistance and simultaneous discrimination of Staphylococcus aureus from coagulasenegative staphylococci. J Clin Microbiol 2004;42:4947-4955.

[19] Gómez P, Lozano C, González-Barrio D, Zarazaga M, Ruiz-Fons F, Torres C. High prevalence of methicillin-resistant Staphylococcus aureus (MRSA) carrying the mec $\mathrm{C}$ gene in a semi-extensive red deer (Cervus elaphus hispanicus) farm in Southern Spain. Vet Microbiol 2015;177:326-331.

[20] Silva NC, Guimarães FF, de P Manzi M, Gómez-Sanz E, Gómez P, Araújo-Júnior JP, Langoni H, Rall VL, Torres C. Characterization of methicillin-resistant coagulase-negative staphylococci in milk from cows with mastitis in Brazil. Antonie van Leeuwenhoek 2014; 106:227-233.

[21] Ziebuhr W, Krimmer V, Rachid S, Loßner I, Gotz F, Hacker J. A novel mechanism of phase variation of virulence in Staphylococcus epidermidis: evidence for control of the polysaccharide intercellular adhesin synthesis by alternating insertion and excision of the insertion sequence element IS256. Mol Microbiol 1999;32:345-356.

[22] Klibi A, Jouini A, Gómez P, Slimene K, Ceballos S, Torres C, Maaroufi A. Molecular Characterization and Clonal Diversity of Methicillin-Resistant and -Susceptible Staphylococcus aureus Isolates of Milk of Cows with Clinical Mastitis in Tunisia. Microb Drug Resist 2018 . doi: 10.1089/mdr.2017.0278. 
[23] Chah KF, Gómez-Sanz E, Nwanta JA, Asadu B, Agbo IC, Lozano C, Zarazaga M, Torres C. Methicillin-resistant coagulase-negative staphylococci from healthy dogs in Nsukka, Nigeria. Braz J Microbiol. 2014;18;45:215-220.

[24] Dziri R, Klibi N, Lozano C, Ben Said L, Bellaaj R, Tenorio C, Boudabous A, Ben Slama K, Torres C. High prevalence of Staphylococcus haemolyticus and Staphylococcus saprophyticus in environmental samples of a Tunisian hospital. Diagn Microbiol Infect Dis 2016;85:136-140.

[25] Hashem AA, Abd El Fadeal NM, Shehata AS. In vitro activities of vancomycin and linezolid against biofilm-producing methicillin-resistant staphylococci species isolated from catheter-related bloodstream infections from an Egyptian tertiary hospital. Ann Clin Microbiol Antimicrob 2017; 10:16-35.

[26] Petzer IM, Karzis J, Watermeyer J, van der Schans TJ, van Reenen R. Trends in udder health and emerging mastitogenic pathogens in South African dairy herds. J S Afr Vet Assoc 2009;80:17-22.

[27] Xu J, Tan X, Zhang X, Xia X, Sun H. The diversities of staphylococcal species, virulence and antibiotic resistance genes in the subclinical mastitis milk from a single Chinese cow herd. Microb Pathog 2015;88:29-38.

[28] Taponen S, Nykäsenoja S, Pohjanvirta T, Pitkälä A, Pyörälä S. Species distribution and in vitro antimicrobial susceptibility of coagulase-negative staphylococci isolated from bovine mastitic milk. Acta Vet Scand 2016;6:58-12.

[29] Kot B, Piechota M, Antos-Bielska M, Zdunek E, Wolska KM, Binek T, Olszewska J, Guliński P, Trafny EA. Antimicrobial resistance and genotypes of staphylococci from bovine milk and the cowshed environment. Pol J Vet Sci 2012;741-749. 
[30] Bochniarz M, Wawron W, Szczubiał M. Resistance to methicillin of coagulase-negative staphylococci (CNS) isolated from bovine mastitis. Pol J Vet Sci 2013;687-692.

[31] Vanderhaeghen W, Piepers S, Leroy F, Van Coillie E, Haesebrouck F, De Vliegher S. Identification, typing, ecology and epidemiology of coagulase negative staphylococci associated with ruminants. Vet J 2015;203:44-51

[32] Mørk T, Jørgensen HJ, Sunde M, Kvitle B, Sviland S, Waage S, Tollersrud T. Persistence of staphylococcal species and genotypes in the bovine udder. Vet Microbiol 2012;159:171-180.

[33] Waller, KP, Aspan A, Nyman A, Persson Y, Andersson UG. CNS species and antimicrobial resistance in clinical and subclinical bovine mastitis. Vet Microbiol 2011; 152:112-116.

[34] Seixas R, Santos JP, Bexiga R, Vilela CL, Oliveira M. Short communication: Antimicrobial resistance and virulence characterization of methicillin-resistant staphylococci isolates from bovine mastitis cases in Portugal. J Dairy Sci 2014;97:340344.

[35] Sawant AA, Gillespie BE, Oliver SP. Antimicrobial susceptibility of coagulase-negative Staphylococcus species isolated from bovine milk. Vet Microbiol 2009;134:73-81.

[36] Holmes MA, Zadoks RN. Methicillin resistant S. aureus in human and bovine mastitis. J. Mammary Gland Biol Neoplasia 2011;16:373-382.

[37] Fernandes Dos Santos F, Mendonça LC, Reis DRL, Guimarães AS, Lange CC, Ribeiro JB, Machado MA, Brito MAVP Presence of mecA-positive multidrug-resistant Staphylococcus epidermidis in bovine milk samples in Brazil. J Dairy Sci 2015;99:1-9. 
[38] Entorf M, Feßler AT, Kadlec K, Kaspar H, Mankertz J, Peters T, Schwarz S. Tylosin susceptibility of Staphylococci from bovine mastitis. Vet Microbiol 2014;16;171:368-373.

[39] Mello PL, Moraes Riboli DF, Pinheiro L, de Almeida Martins L, Vasconcelos Paiva Brito MA, Ribeiro de Souza da Cunha Mde L. Detection of Enterotoxigenic Potential and Determination of Clonal Profile in Staphylococcus aureus and Coagulase-Negative Staphylococci Isolated from Bovine Subclinical Mastitis in Different Brazilian States. Toxins 2016;15:8-104.

[40] Martins KB, Faccioli PY, Bonesso MF, Fernandes S, Oliveira AA, Dantas A, Zafalon LF, Cunha MLRS. Characteristics of resistance and virulence factors in different species of coagulase-negative staphylococci isolated from milk of healthy sheep and animals with subclinical mastitis. J Dairy Sci 2017;100:2184-2195. 
Table 1 Phenotypes and genotypes of antimicrobial resistance and types of SCCmec in MR-CNS recovered from milk samples of clinical mastitis

\begin{tabular}{|c|c|c|c|c|c|c|c|c|}
\hline Strain & species & $\begin{array}{l}\text { Resistance } \\
\text { to OXA or } \\
\text { FOX }\end{array}$ & $\operatorname{mec} \mathrm{A}$ & mec $\mathrm{C}$ & $\begin{array}{l}\text { Resistance } \\
\text { phenotype }\end{array}$ & $\begin{array}{l}\text { Resistance } \\
\text { genes }\end{array}$ & $\begin{array}{l}\text { Virulence } \\
\text { gene }\end{array}$ & $\begin{array}{l}\text { SCCmec, } \\
\text { class mec, } \\
\text { ccr type }\end{array}$ \\
\hline EC70 & S. scuiri & OXA & $m e c \mathrm{~A}$ & & ERY, CLI & blaZ, erm(B) & - & \\
\hline EC186 & S. warneri & OXA, FOX & $m e c \mathrm{~A}$ & & PEN, CLI, CIP & blaZ, & - & \\
\hline EC196 & $\begin{array}{l}S . \\
\text { epidermidis }\end{array}$ & OXA, FOX & mecA & & PEN, TET, SXT & blaZ, dfr(A) & - & IVa, (B, \\
\hline EC201 & $\begin{array}{l}S . \\
\text { epidermidis }\end{array}$ & OXA, FOX & mecA & & PEN, ERY, SXT & $\begin{array}{l}\text { blaZ, msr(A), } \\
d f r(\mathrm{~A})\end{array}$ & & $\begin{array}{l}\text { IVa, (B, } \\
c c r \mathrm{~A} 2 / \mathrm{B} 2)\end{array}$ \\
\hline EC207 & $\begin{array}{l}\text { S. } \\
\text { epidermidis }\end{array}$ & OXA, FOX & mecA & & $\begin{array}{l}\text { PEN, ERY, TET, } \\
\text { GEN, TOB, STR, } \\
\text { SXT, CIP }\end{array}$ & & & $\begin{array}{l}\text { IVa, (B, } \\
c c r \mathrm{~A} 2 / \mathrm{B} 2)\end{array}$ \\
\hline EC134 & $\begin{array}{l}S . \\
\text { epidermidis }\end{array}$ & OXA, FOX & mecA & & $\begin{array}{l}\text { PEN, ERY, CLI, } \\
\text { TET, GEN, SXT, }\end{array}$ & & - & $\begin{array}{l}\text { IVa, (B, } \\
\operatorname{ccr} \mathrm{A} 2 / \mathrm{B} 2)\end{array}$ \\
\hline EC200 & $\begin{array}{l}\text { S. } \\
\text { haemolitycus }\end{array}$ & OXA, FOX & mecA & & CIP,STR,SXT,CHI & $\begin{array}{l}\text { blaZ, } \operatorname{msr}(\mathrm{A}), \\
\operatorname{tet}(\mathrm{K}), \operatorname{erm}(\mathrm{C}), \\
d f r(\mathrm{~A})\end{array}$ & - & \\
\hline EC195 & $\begin{array}{l}\text { S. } \\
\text { haemolyticus }\end{array}$ & OXA, FOX & mecA & & 'EN, ERY, CLI, & blaZ, tet $(\mathrm{K})$ & - & \\
\hline EC 6 & S. pasteuri & OXA, FOX & & & $\begin{array}{l}\text { PEN, ERY, CLI, } \\
\text { STR, SXT, TET }\end{array}$ & $\begin{array}{l}\text { blaZ, } m s r(\mathrm{~A}), \\
\operatorname{tet}(\mathrm{K})\end{array}$ & - & \\
\hline EC84 & S. pasteuri & & & & $\begin{array}{l}\text { PEN, ERY, CLI, } \\
\text { STR, SXT }\end{array}$ & blaZ & - & \\
\hline EC53 & S. pasteuri & DX, FOX & mecA & & PEN, STR & blaZ & - & \\
\hline EC199 & S. pasteuri & $\mathrm{OXA}$ & mecA & & - & - & & \\
\hline EC39 & $S$ & OXA & mecA & & - & - & tsst-1 & \\
\hline EC60 & S. cohnii & OXA, FOX & mecA & & PEN, CLI & blaZ & - & \\
\hline $\begin{array}{l}\text { EC22.1 } \\
\text { EC119 }\end{array}$ & S. xyosus & $\begin{array}{l}\text { OXA, FOX } \\
\text { OXA, FOX }\end{array}$ & - & - & $\begin{array}{l}\text { PEN, CLI, ERY } \\
\text { PEN, CLI, ERY }\end{array}$ & $\begin{array}{l}\text { blaZ, } \\
\operatorname{erm}(\mathrm{B}), \operatorname{msr}(\mathrm{A}) \\
m p h(\mathrm{C})\end{array}$ & - & \\
\hline EC104 & S. scuiri & OXA, FOX & - & - & PEN, ERY, CLI & $\begin{array}{l}\operatorname{blaZ}, \operatorname{erm}(\mathrm{T}) \\
, \operatorname{msr}(\mathrm{A})\end{array}$ & - & \\
\hline EC136 & S. warneri & OXA, FOX & - & - & PEN, CLI & - & - & \\
\hline EC161 & S. warneri & OXA, FOX & - & - & PEN, CLI, STR & - & - & \\
\hline EC193 & S. equorum & OXA, FOX & - & - & PEN, CLI & blaZ & - & \\
\hline Total & 20 & & 14 & 0 & & & & \\
\hline
\end{tabular}


OXA oxacillin, FOX cefoxitin, PEN penicillin, STR streptomycin, TET tetracycline, CLI clindamycin, ERY erythromycin, TOB tobramycin, GEN gentamicin, CIP: ciprofloxacin, SXT trimethoprim-sulfamethoxazole, CHl chloramphenicol, tsst-1: toxic shock syndrome toxin 1 gene

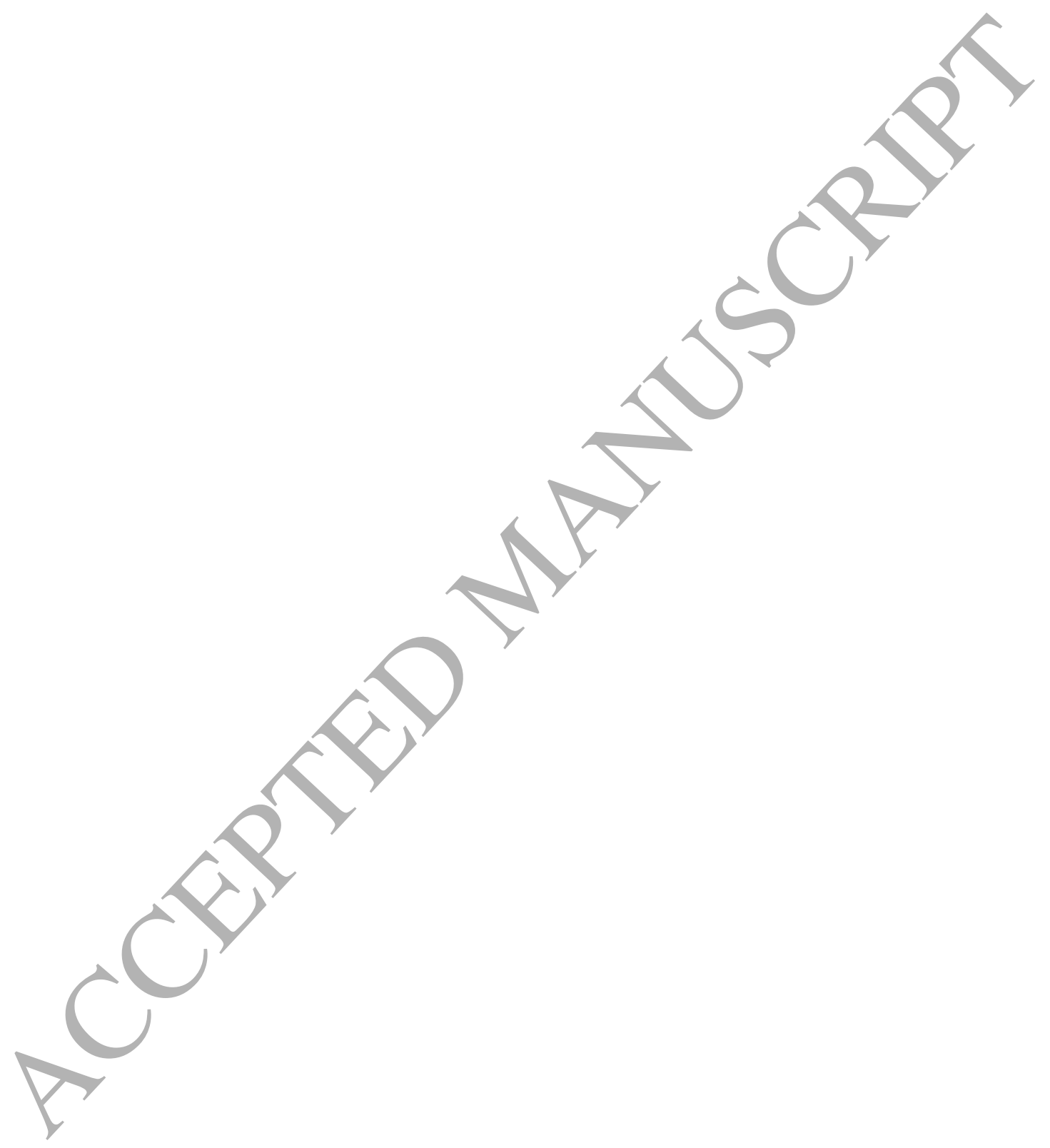


Table 2 Antimicrobial resistance phenotype and genotype of MS-CNS recovered from milk samples of clinical mastitis in Tunisia.

\begin{tabular}{|c|c|c|c|c|}
\hline Strain & Species & Phenotype resistance & Resistance gene detected & Virulence gene detected \\
\hline EC15 & S. xylosus & TET & $\operatorname{tet}(\mathrm{K})$ & - \\
\hline EC16 & S. xylosus & PEN & blaZ & - \\
\hline EC19.1 & S. xylosus & PEN & - & - \\
\hline EC27 & S. xylosus & PEN & - & - \\
\hline EC29.1 & S. xylosus & PEN & - & - \\
\hline EC31.1 & S. xylosus & PEN & - & - \\
\hline EC31.2 & S. xylosus & PEN, STR & blaZ & - \\
\hline EC32 & S. xylosus & PEN & - & 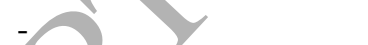 \\
\hline EC43 & S. xylosus & PEN & blaZ & \\
\hline EC55 & S. xylosus & PEN & - & \\
\hline EC105 & S. xylosus & PEN, ERY & blaZ & \\
\hline EC106 & S. xylosus & PEN & - & - \\
\hline EC45 & S. xylosus & PEN & blaZ & - \\
\hline EC165 & S. xylosus & PEN & - & - \\
\hline EC150 & S. xylosus & PEN & - & - \\
\hline EC157.1 & S. xylosus & PEN, CLI & blaZ, & - \\
\hline EC157.2 & S. xylosus & PEN & - & - \\
\hline EC162 & S. xylosus & PEN & & - \\
\hline EC163 & S. xylosus & PEN & - & - \\
\hline EC172 & S. xylosus & - & - & - \\
\hline EC177 & S. xylosus & PEN, STR, SXT & blaZ & - \\
\hline EC195 & S. xylosus & PEN & blaZ & - \\
\hline EC199 & S. xylosus & PEN & $y^{\prime}$ & - \\
\hline EC205 & S. xylosus & PEN & - & - \\
\hline EC209 & S. xylosus & PEN & blaZ & - \\
\hline EC68 & S. scuiri & PEN & - & - \\
\hline EC78 & S. scuiri & - & - & - \\
\hline EC99 & S. scuiri & PEN & - & \\
\hline EC10 & S. warneri & PEN, ERY, CLI & blaZ, $\operatorname{erm}(\mathrm{C}), \operatorname{msr}(\mathrm{A})$ & - \\
\hline $\mathrm{EC} 12$ & S. warneri & ERY, CLI & $\operatorname{erm}(\mathrm{C}), \operatorname{msr}(\mathrm{A}), \operatorname{erm}(\mathrm{T})$ & - \\
\hline $\mathrm{EC} 23$ & S. warneri & & - & - \\
\hline EC93 & S. warneri & & - & - \\
\hline EC103 & S. warneri & & - & - \\
\hline $\mathrm{EC} 17$ & S. epidermidis & PEN, STR, TET & blaZ, $\operatorname{tet}(\mathrm{K})$ & - \\
\hline EC24 & S. heamolitycus & $y$ & - & - \\
\hline EC101 & S. heamolitycus & - & - & - \\
\hline EC19.2 & S. chromogenes & - & - & - \\
\hline EC72 & S. chromogenes & - & - & - \\
\hline EC155.1 & S. chromogenes & ERY & - & - \\
\hline EC155.2 & S. chromogenes & - & - & - \\
\hline EC187 & S. chromogenes & - & - & - \\
\hline EC34 & S. saprophyticus & PEN & - & - \\
\hline EC212 & S. saprophyticus & - & - & - \\
\hline EC52 & S. succinus & PEN & - & - \\
\hline EC64 & S. succinus & PEN & blaZ & - \\
\hline EC191 & S. succinus & PEN & - & - \\
\hline EC208 & S. pasteuri & - & - & - \\
\hline EC102.1 & S. equorum & TET & $\operatorname{tet}(\mathrm{K})$ & - \\
\hline
\end{tabular}


PEN penicillin, STR streptomycin, TET tetracycline, CLI clindamycin, ERY erythromycin,

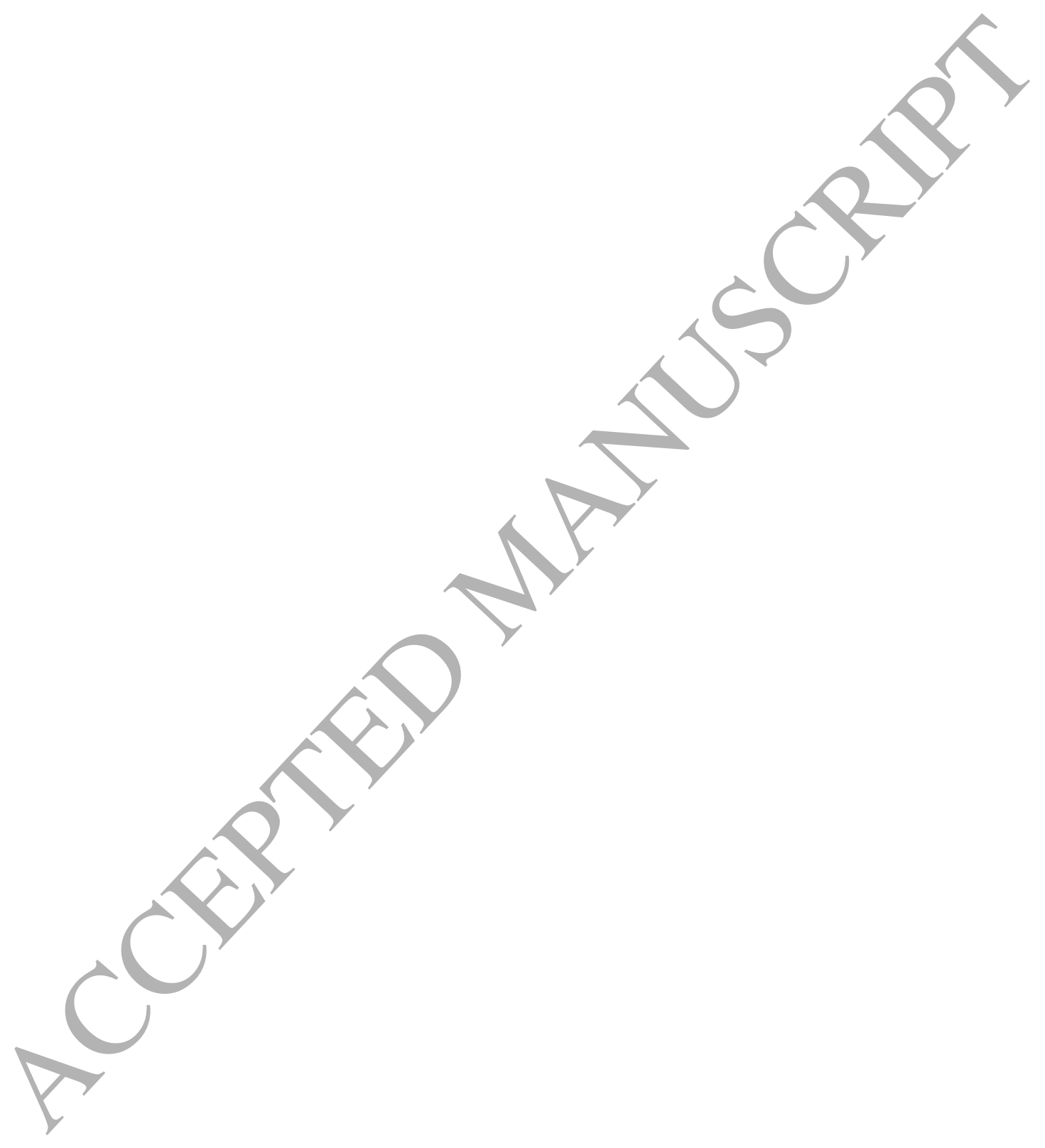

